\title{
A Study of Courses Construction in Credits System Reform
}

\author{
Zhao Shurong
}

\begin{abstract}
Courses system construction, being the core content and prerequisite of credits system construction, is confronted with various problems including the inadequacy of courses and qualified teachers, the rigidness of teaching idea of teachers and learning method of learners and the dilemma situation in rules drawing-up to balance the requirement of unification and difference among disciplines. Measures should be taken to increase quantity and boost quality of courses, which include arousing the curricular consciousness of teachers, carrying out needs analysis, constructing common courses platform, procuring Moocs or micro-lectures, adopting strict courses access standards and performing stringent process and result assessment.
\end{abstract}

Index Terms-Credits system, courses system construction, curricular consciousness.

\section{INTRODUCTION}

Credits system is a kind of educational regime and mode of teaching management originating from universities of western countries, which takes system of selecting subjects as its focus. Therefore courses system construction becomes significant in the process of turning academic year system into credits system. And during this turning phase, the courses development and enrichment is confronted with various problems, while at the same time, certain teaching or cultivating objectives must be met, which constitutes similar circumstance of dancing with fetters to that of translation. So in order to realize the smooth transfer into credits system, effective measures must be taken to ensure the sound development and enrichment of courses system, which becomes a key issue.

\section{CREDITS SYSTEM AND COURSES SYSTEM CONSTRUCTION}

\section{A. Credits System}

Credit originally means public approval or praise given to someone because of something they have done, and under educational circumstance, it means the units students acquired after accomplishing certain task or the learning of certain subject. And courses credits system refers to mode of teaching management which requires students to select and then accumulate fixed amount of credits to finish their academic record and get their diplomas.

Credits system is a kind of teaching management regime, which embodies a teaching perspective granting full respect

Manuscript received March 24, 2017; revised September 2, 2017.

The author is with the Shandong Women's University, No. 2399, Daxue Road, Changqing district, Jinan, China (e-mail: zhrong9411@163.com). to the learners' autonomy or freedom in scheduling and arranging for their study [1]. Humanism, the theoretical foundation of credits system, takes its origin from the idea of academic freedom, teaching and learning autonomy put forward by William Humboldt, the German educator. Inspired by Humboldt's idea, Harvard University of the United States put courses selection system on trial among its junior and senior students, and carried out officially the credits system from the late 19th century. After consistent exploration and development of more than 100 years, mature and sound rules and practice of credits system took form, which also expanded to many other universities of America. The successful enforcement of credits system brought about significant influence on the higher education of America. The quantity of courses adapting to social development soared, and teaching and learning mode transferred, which nurtured diversified talents. The credits system also becomes a significant tag of American higher education. The credits system also developed rapidly in England. It can be noted that credits system indicates the combination of teaching management systems of Germany, England and the United States, and embodies the fruits of higher education in the world [2].

Credits system is a kind of teaching management regime, which embodies a teaching perspective granting full respect to the learners' autonomy or freedom in scheduling and arranging for their study [1].

The major elements of credits system cover flexible length of schooling, dual degrees (major and minor), and rules of selecting courses, which all indicate the pursuit the learning freedom. And the freedom means that students may arrange for the schedule of their study, choose the teachers they like and decide the portfolio of courses in the academic pursuit. The credits system overturns to some extent the mode of teaching and learning of academic year system, adapts to the diversified requirements from social development, respects the difference of individuals and becomes a recognized teaching mode.

In the late 20th century, pushed by the social and economic development and reform in the education field, credits system was introduced to China. Universities with abundant educational resources like Peking University and Tsinghua University launched reforms of transforming existing teaching management system to credits systems, and some other universities followed the steps and carried out trial at different degrees. Various forms of credits system appeared during the process of exploration. From the perspective of national policy, the National education reform and development of long-term planning programs (2010-2020) requires educational institutions to try to develop the 
potential of each student, carry out various reforms including stratified teaching, tutorial system, compound credit system and class selection system. The program also urges to develop perspective of talents diversity, respect students' choices and encourage development of personality. This overall guideline makes clear the necessity and upcoming trend of development of credits system. Furthermore, under the current social and economic status, with the policy emphasis on innovation and entrepreneurship, another round of credits system reform is expected to feature encouragement of innovative learning, taking market competition into consideration, and taking flexible management system as insuring force [3].

\section{B. Courses System Construction}

Courses contain the major process of passing on knowledge and is the fundamental cell and constituent of teaching. The achievement of teaching objectives, whether it's the objective of the chapter, of the subject and the cultivating goal of education, relies to large extent on the basic vehicle of courses. And the courses system embodies the interrelations of different knowledge or competency modules, represents certain educational perspective and intention and decides the forming of distinct characteristics. Courses and courses system are the major realizing methods of cultivating goals for higher education institutions, while not being confined within the campus. Their achievements link closely to the progress of economic and cultural development and reflect indirectly the social development.

Credits system means a new mode of allocation of educational resources, which to large extern are courses resources. And the principal realizing method of distributing educational resources is to implement courses selection system. During the more than 100-year exploration of credits system of Harvard University, the core of reform remained in the change of courses selection, from the original courses selection system to free selection, centralized distribution and finally to core subjects system. The exploration of credits system reform coincided with the change and perfecting of courses system construction.

In the reform of transforming into credits system in China, the prerequisite of reform is to deal with properly courses system construction issues, especially the establishment and improvement of courses selection rules, the enriching of abundant courses resources, the ensuring of courses quality. To keep the construction of courses system in line with orientation and practical status of the higher education institutions also matters greatly. The traditional academic year system emphasizes on specialized knowledge of each discipline and assigns large proportion of compulsory courses and small proportion of selective courses in the curriculum, going contrary to the idea of credits system that covers across discipline boundaries and devotes to cultivate talents with wide scope of knowledge of broad vision. Therefore in the transferring process from academic year system to credits system courses system is a key issue and it's an indispensable part of reform to reinforce the overall courses system and individual course development, to increase the supply of courses resources and ensure the quality of courses teaching [4].

\section{OBSTAClES IN COURSES SYSTEM CONSTRUCTION DURING CREDIT SYSTEMS REFORM}

\section{A. Insufficiency of Courses and Faculty}

Credits system aims to cultivate talents with diversified scope of knowledge and endows students with the right to select courses and teachers in accordance with their own learning schedule. It urges institutes to offer large amount of quality courses, whether compulsory or selective, for their choice, which constitutes the basis of credits system. In addition, each course must be offered every term to satisfy the needs of flexible academic schedule and retaking, be offered by at least two teachers to give options for students which is one important element of credits system. It therefore calls for sufficient amount of teachers. But the current situation shows that compulsory courses occupy much more proportion than selective courses, the latter with unsatisfactory quality. It's requisite to cope with the requirements of credits system as to the amount of selective courses while to increase the supply of selective courses greatly within a short period seems unrealistic considering the existing status of institutes. As to faculty, the quantity of teachers has already been stretched thin in most higher education institutions and in addition it's impractical to enroll in big amount of teachers. Even in institutes with comparatively abundant supply of teachers, there exists disciplines with high degree of specialization, such as medical majors, for which it's impossible to share faculty with other majors.

\section{B. Rigidness of Modes of Teaching}

Credits system means totally different management mode from the traditional one and brings about great change in teaching, for instance, the cut down in teaching hours and total credits, completely different needs of learners and teaching objectives. All these constitute challenge to the mode of teaching and calls for new conception in teaching. But under the long-term influence of traditional mode teachers possess simple knowledge structure and may feel difficult to absorb knowledge from other disciplines. Therefore there exists gap between the knowledge or competency of teachers and the needs from learners. And in addition the new mode urges teachers to reconstruct the teaching plan, compressing the class lecture and encourage after class learning. Also, the emphasis on individualized teaching and personality development advocated by the new mode look indicates significant transfer as the traditional mode focuses on collective development and progress. And it will be difficult for most teachers to adapt to this change.

\section{Dilemma in Rules Formulation}

To carry out credits system, there must be some corresponding rules and regulations, including the rules of courses selection, the tutorial system, the retaking rules and the tuition-charging systems. These rules and regulations should function as guidelines orienting positive trend of development and should be strict and unified so as to ensure the smooth execution of reform. But this rigidness and unification conflict with the differentiated development of various disciplines. Each discipline cultivate learners with specific emphasis and there're different guidelines in the 
design of curriculum from their respective advisory boards, which results in diversified degree of adaption to credits system. Taking foreign language majors as example, although all the majors offer reading, listening, speaking, writing and translation courses, it's impossible for them to constitute a common courses platform. An English learner cannot choose listening course in Russian. Moreover, there's fixed order in learning these subjects, so completely free choice of courses seems impractical. In addition, there's little sense to break the border of majors, as what's advocated by credits system reform. So, to respect the difference among disciplines or to pursue the unification of rules constitutes a dilemma for rules makers.

\section{Insufficient Exterior Support}

Higher education institutions with successful exploration and mature credits system share the common characteristic of sound and supportive exterior environment. In America, the cross-school selection of subjects and credit transfer are very popular, which greatly increase the supply of selective courses. South Korea carried out school credit bank, which allows students to accumulate credits from credits offering institutions, even after their graduation from schools. Therefore the concept of lifelong learning is deeply rooted among people. This exchange among colleges and society equipped school education with social elements and brings about closer link between social needs and talents cultivation. In China, although several universities tried similar measures, it's still in elementary stage, far from mature state. And for most institutions, there's rare exchange in courses offering, considerable obstacles for credit transfer and cross-school courses selection, not to mention the credit transfer with social institutions. There're also no policies or regulations to support this kind of interchange.

\section{APPROACHES TO COURSES SYSTEM CONSTRUCTION}

\section{A. Make Clear the Train of Thought and Carry out Thoughtful Top-Level Design}

Clarify the key issues. During the process of transfer, curriculum design and courses system construction should target the training objectives of the major and overall cultivating goal, taking the practical situation of the school into consideration. The construction of courses system should center on the educational goal and the latter decides which kind of teaching method should be adopted. Two key issues should be dealt with during the transfer process as to the courses construction. The first one is about the choice of courses in the system and their breadth and depth. The second issue lies in the coherence and coordination of different courses in the system [5].

Follow some basic principles in courses construction. The credit system was introduced from foreign countries, mechanical imitation should be avoided during the process of localization, because of marked difference in interior and exterior conditions. Also it goes to an extreme to totally repudiate the traditional academic year system and deny all the past endeavor. Some basic principles should be observed during the reform design. Firstly, finite freedom or free choice with some limits. Credits system grants students choice of learning content the arrangement learning schedule, while choices depending solely on interest leads to imbalance in the knowledge structure and results in the situation of popularity of easy lectures and being left out of important but difficult courses. The selection of courses must be carried out by guidelines and limitations so as to bypass the above-mentioned problem. And it's the duty of teaching administrator to pay efforts in collaborating these guidelines. Secondly, wide scope of knowledge on the basis of ensuring core competence. Credits system allows students to have cross-school and cross-discipline courses selection. Although it contributes to broad knowledge structure, it tends to lead to scattered knowledge of students. So it's essential to arrange for appropriate proportion of compulsory courses and selective courses, ensuring both core competence of the major and broad vision. Thirdly, learners' autonomy under adequate instruction. Teachers' role as instructor should be given full play to guarantee rational choice during the process of courses selection and scheduling. Also, under the situation of class hour cut down, teachers should pay adequate efforts in the instruction and supervision of after class learning. Fourthly, strict rules with certain extent of sense of inclusion. The characteristics of different major should not be neglected and rules should be formulated with sense of inclusion. It's unwise to seek unification just because of management convenience.

Carry out need analysis. There're some theories and guidelines as to curriculum design. According to Hutchinson [6] and Yalden [7], the first step in curriculum design is to carry out needs analysis, and this step also has certain influence on the other steps. Needs analysis contains analyzing target needs as well as learning needs. During the transfer process, it's essential to investigate target needs in relative industries or sectors so as to keep the curriculum in line with social development, to investigate learning needs of students in order to construct well-targeted courses structure.

\section{B. Transform the Teaching and Learning Concept}

The success of Harvard University's courses system construction attributes greatly to the wide participation and involvement of all the teaching staff and students. In China, under the circumstance of complicated interior and exterior situation and solidified teaching concept, the implementation of credits system also calls for wide participation and active cooperation from the teachers and students. They may offer practical first-hand suggestions in the implementation of credits system, which is really valuable in rules and guidelines formulation.

For teachers, to accord with the new requirements of credits system, it's necessary to awaken the courses consciousness and transform the teaching idea. Courses consciousness refers to an active reflecting behavior in course design, lecture giving and teaching assessment [8]. At present, the awakening of courses consciousness calls for teachers to keep a sense of course development and habit of reflection, involving themselves actively in the improvement of existing courses and development of new courses. Also teachers are expected to change the original habit of focusing on compulsory courses and ordinary students while 
neglecting selective courses and retaking students, which goes apparently contrary to the basic concept and principle of credit system.

The smooth pushing forward of courses system construction also calls for the all-round participation of students. As the master of their own study, students should involve themselves in the procedure and consistently deepen their comprehension of their major and the courses they are to learn or choose. The in-depth and rational understanding will help achieve efficient courses selection and goals of education.

\section{Adopt Various Measures to Increase Supply of Courses and Guarantee Quality of Courses}

Push forward the construction plan in an orderly way and step by step. Premature advance in quantity comes along with sacrifice of quality. Based on the present situation, courses construction may be initiated from general courses, with relatively lower difficulty. It's advisable to utilize the resources of the whole campus, classify different modules and encourage teachers to develop courses which meet both their specialty and the needs of the students. After drawing lessons from the general courses, it's appropriate to initiate the enrichment of specialized courses.

Make or procure online courses. Online courses like Moocs and micro-lectures become very popular in recent years, attracting learners with vividness in passing on knowledge, availability all time and large scale sharing. Also favored by the preferential policy from government authority large amount of online courses were produced and listed on various online courses platforms. Under such a circumstance, it becomes a shortcut to purchase online courses or make their own ones depending on their own faculty so as to solve the problem of shortage in courses supply. On the other hand, this process must be carried out cautiously, as the online courses, experiencing a short time sharp increase, are of varying quality. And although the merits of online courses seem apparent, the defects of them are also obvious, especially in the interaction between teachers and students, and the enforcement of homework or tasks. If online courses are to be absorbed in the courses system, there must be certain amount of face-to-face teaching or question-solving hours to help reinforce the knowledge and guarantee the quality of courses.

Draw up rules to encourage taking-up and development of courses. Teachers play a major role in courses system construction. During the process of transfer to credits system, teachers are faced with much larger quantity of teaching hours, as retaking courses, minor major courses and consistent offering of compulsory courses each term multiply the teaching hours. Furthermore, they have to develop considerable amount of new courses to settle the problem of selective courses shortage and to enrich the choice of students. Under such situations, if teachers are reluctant to participate actively, all the major steps in courses system will be in vain. Therefore the teaching management bodies should draw up rules, regulations and policies which effectively encourage and support teachers to take up more courses, to develop new courses and to enrich their own knowledge structure, so as to improve their competence of teaching and adapting to the new mode of teaching.

Utilize all interior and exterior sources to enrich courses resources. Many institutes adopted exploratory attempts to settle the problem of courses shortage, which offers valuable reference for others who still are in the process of exploring. Shenzhen Polytechnic organized majors with common discipline foundation and characteristics into groups, and majors within the same group share common basic courses, which to large extent solve the shortage problem with limited investment. Guangdong University of Foreign Studies signed agreements of credits transfer with several universities from home and abroad, and accept credits students acquired from authorized online courses platform. Hebei Normal University made some new approach to the credits system of English major. All the courses of English major were classified into two groups, basic courses and module courses, the former being compulsory and the latter being for selection. The module courses in turn fall into 8 modules including linguistics, literature, teaching methods, translation and etc. Students can choose among the 8 modules and pursue all the courses in that module. This approach ensures core competence and diversified orientation of students [9]. Tianjin University absorbed after-class practice into credits system and formed all-round cultivating system [10].

\section{CONCLUSION}

The transfer from academic year system to credits system conforms to the social and economic development by targeting its requirements to higher education, and will still be a general trend in the coming years. It should be noted that there's a long way to go in the process of transform since it's a rather complicated systematic cause and there must be ups and downs. Large amount of work should be done to identify the core status of courses construction, set down the specific goals of reform and utilize both internal and external forces. It's also necessary to explore the internal law of the reform, draw up and revise the train of thought and outline, and to pay joint efforts. In this way the construction of flexible courses system meeting both target and learning needs will be finally achieved.

\section{REFERENCES}

[1] C. L. Xue and D. G. Wu, "On the essence and functions of the credit system: The correlation between the credit system and the educational resources allocation," Peking University Education Review, vol. 7, pp. 138-156. 2007.

[2] X. J. Cai, "The formative logic of college credit system," Journal of Higher Education, vol. 6, pp. 8-18, Jun. 2006.

[3] F. M. Wang and F. C. Liu, "Rational reflection on credit system reform in Chinese universities," Review of Higher Education, vol. 11, pp 51-56. Nov. 2016.

[4] G. X. Cai, "An analysis of courses in the credits system reform for higher education institutions," The Guide of Science \& Education, vol. 4, pp. 20-21, Apr. 2015.

[5] X. Y. Wang and X. Y. Liu, "On China's credit system reform from the perspective of elective course reform in Harvard University," The Science Education Article Collects, vol. 5, pp. 34-35. May. 2013.

[6] T. Hutchinson and A. Waters, English for Specific Purposes, London, U. K.: Cambridge University Press: 1987, pp. 15-18.

[7] J. Yalden, Principles of Course Design for Language Teaching, London, U.K.: Cambridge University Press: 1987, pp. 4-5.

[8] Y.-A. Yin, "The Inter-disciplinary Talent cultivation and career development of teachers," Journal of Southwest University for 
Nationalities (Humanities and Social Science), vol. 11, pp. 159-161. Nov. 2009.

[9] M. Feng, S. L. Ji, and H. S. Li, "The formulation and implementation of English course modules within the frame of full credit system," Foreign Languages in China, vol. 5, pp. 77-81. Oct. 2008.

[10] Q. Wang, D. G. Ma, and Y. D. Li, "On extracurricular practice education reform models in universities," Heilongjiang Researches on Higher Education, vol. 6, 142-146, Jun. 2016.

Zhao Shurong was born in Zibo, Shandong province, China, on Sep $15^{\text {th }}, 1975$. She got the bachelor's degree for economics from Shandong Finance and Economics University in 1998, and the master's degree for economics from Capital University for Economy and Trade in 2002. Her major field of study is higher education management and teaching methodology.
She took up the teaching job in Shandong women's University in 1998 teaching lessons of business English and finance English. From 2007, she was appointed vice dean of the foreign language school, and went in for teaching management. Previous publications include: A Study of English Profiles of Foreign Trade Enterprise on B2B E-commerce Platform from Genre Approach, published by the Changchun University Journal in 2013, a Study on the Application of Reading Logs in After-class Reading, published by the Journal of Inner Mongolia Normal University (Educational Science).

Prof. Zhao works as the standing director of the business English association of Shandong province. 